\title{
Trends in change of times of sowing of soft winter wheat (Triticum aestivum L.) in South part of Right-bank Forest-steppe of Ukraine at climate change
}

Ulich 0.

Blagoveshchensk Branch of SE "Center for certification and expertise of seeds and planting material», Novoselytsia, Blagoveshchensk region, Kirovograd oblast, 26423, Ukraine; e-mail: ulich23@ukr.net

The purpose. To study trends in change of time of sowing of winter wheat at climate change and use of innovative grades with selection of the best of them. Methods. Field, laboratory, statistical. Results. For the first time in South part of Right-bank Forest-steppe of Ukraine trends in change of time of sowing of winter wheat are studied at aridization of climatic conditions, global warming and use of modern grades and nano-technologies. In 1950-s the best terms were on August, 25, in 1970-s - 10, in 1980-s - 10-15, in completing decade - on September, 20. In the last years they observed drought, and significant extension of time of autumn vegetation of plants. It brings in essential updating time of sowing. For years of present century winter wheat forms the highest productivity at sowing on September, 30. In 1950-s winter crops, sown before optimum time, formed productivity above, than sown later, and since 1980th late sowings of winter wheat were more productive. The probability of deriving high productivity at early sowing makes $6 \%$, at admissible early -24 , at optimum -61 , at late $-9 \%$. Distinctive features of adaptive response to time of sowing of different genotypes are determined. Conclusions. The trend is determined in shift of time of sowing of winter wheat aside more later in comparison with time of sowing in 1950-s for 30 days, in 1970-s - 20, in 1980-s - 15-20, in 1990-s - for 10 days. Nowadays optimum time of sowing of winter wheat is September, 30 , and it is largely depends on genotype.

Key words: productivity, climatic conditions, winter-hardiness, grade.

$$
\text { https://doi.org/10.31073/agrovisnyk201806-03 }
$$

Formulation of the problem.In the complex of agro technical measures to grow high-yielding winter wheat cropquite aweighty place belongs to the terms ofits sowing. It is important to sow it at optimal timing. In different soilclimatic zones, the sowing times range from the beginning of September and up to the middle of October. Recommendations on optimal and permissible sowing dates are being developed based on the generalized data of scientific researches and breeding establishments. But due to the transformation of the climate, as well as the introduction of modern innovation varieties and nanotechnologies, producers have to review approaches to the timing of sowing.

Analysis of basic research and publications.Scientists of Ukraine have accumulated a significant experimental material regarding the timing of winter wheat sowing. S.A. Vorobyov admits that early cropsbetter survive the winter than laterones[1]. Most scholars believe that early cropscan overgrow; they havelesser winter resistance and they form lower productivity [2-12]. According to Myronivsky Institute of Wheat named afterV.M.Remesla, winter wheat is better to be sownwhen the average daily temperature is $14-16^{\circ} \mathrm{C}$ [3]. O.A. Demydov argues that the optimal timing of sowing tends to be shifted toward the laterone [4]. M. Lytvynenko and S. Lyfenko indicate that the new varieties are characterized by a shorter period of vernalization and a smaller photoperiodicity [5]. Taking into account the length of vernalization, winter wheat can be sown in winter windows, but the best time to do it is within 20-30 September [6]. In Central Forest-steppe the optimal time also falls on the period from September 20 to September 30 [7], in East of Ukraine from September 20 to October 5 [8], in Southern Steppe from September 30 to October 10 [9]. Studies of the Institute of Irrigated Agriculture have confirmed that under arid conditions, the winter wheat can be sown in this zone until October 15-20 [10,11]. In conditions of the Rostov region (Russian Federation), the optimal term for sowing is September 30 [13]. Intensive technology of growing winter wheat in Germanytends toearly sowing [14], in Belgium it's on the contrary -toward a later date [15].

Consequently, as one can see from the foregoing, there is no single scientifically grounded approach toward the timing of winter wheat sowing in literary sources, so this problem is very relevant now. Moreover, in the modern period, sowing out ofobsolete recommendations is not acceptable at all, because the data was obtained under other climatic conditions, agro technologies and varieties. It is appropriate and recommended that the process of studying the timing of sowing be permanently active.

Goal.Study of tendencies of changing the timing of winter wheat sowing in the Southern part of the Pravoberezhny(Right Bank) Forest-steppe of Ukraine in terms of transformation ofthe climatic conditions and modern innovation varieties; detecting the level of their productivity at different sowing times and determining the best ones. 
Methods and conditions. The methodical basis for conducting researches was the Methodology of state variety testing of agricultural crops and expert examination of plant varieties of grain cereals, cerealcrops and grain legumes with regard to their eligibility for distribution in Ukraine [16-18]. The researches were carried out in the Kirovohrad State Plant Research Station (the former Ulyanovsk State Sorting Station), which is currently reorganized into the BlagoveshchenskBranch of the State Enterprise "Center for Certification and Examination of Seeds and Planting Material". Soils of the experimental field areregraded black earth soils with a content of humus in the arable layer of $4,05 \%$. The technique of carrying out of agricultural experiments is generally accepted for the given zone. In the fifties, extensive cultivars were investigated and in the subsequent periods - intensive and high intensity ones. In addition to productivity of varieties, other agronomic-valuable properties of varieties were studied as well.

Results.Studies show that in the fifties of the last century, same as now, the terms of winter wheat sowing had a significant impact on the growth and development of plants and productivity of crops as well (Fig. 1).

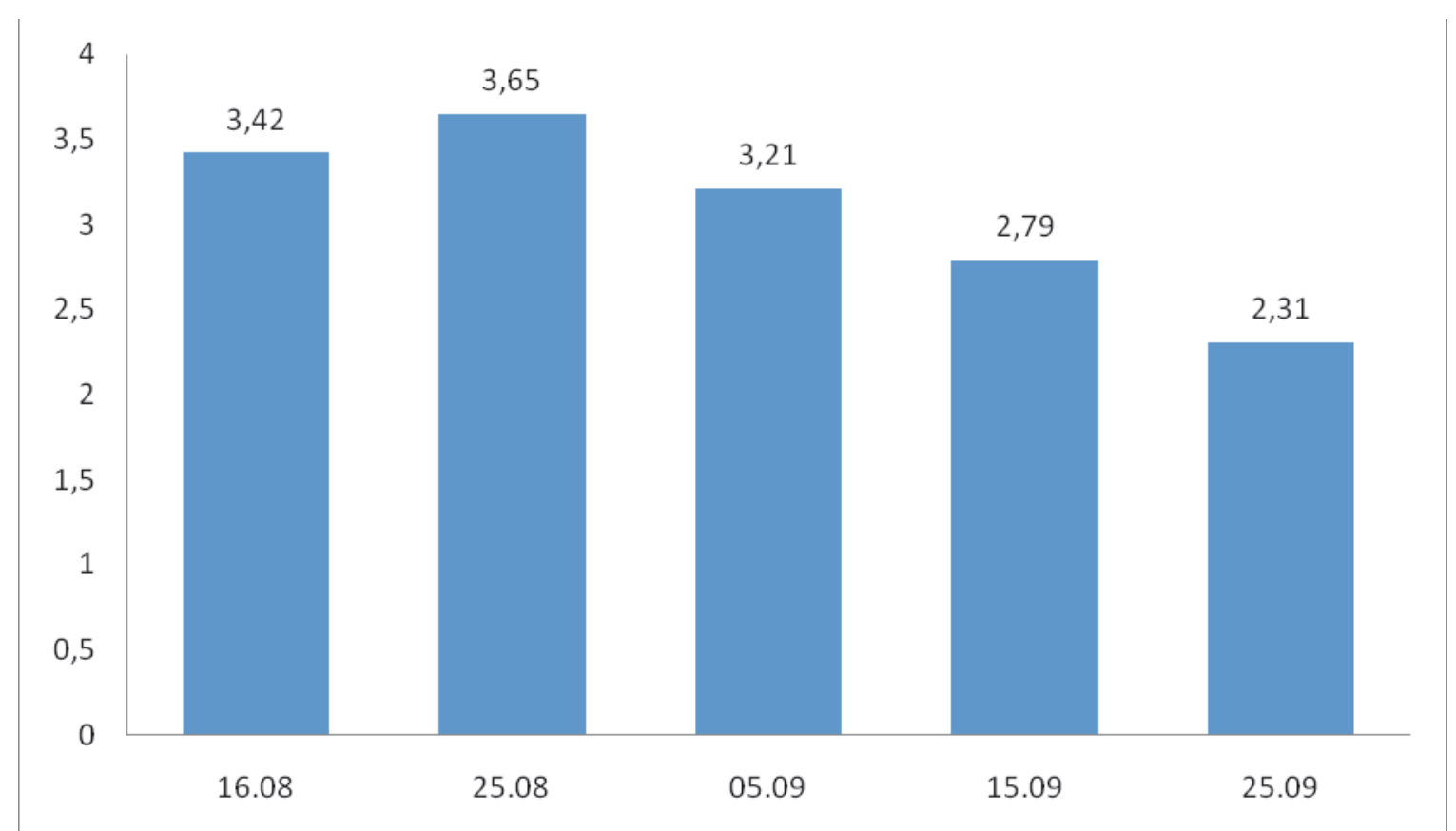

Fig. 1. Yield of winter wheat, depending on the timing of sowing, Ulyanovsk State Sorting Station, the year of 1955, $\mathrm{t} / \mathrm{ha}$

Apparently, winter wheat produced the highest yields of 3.65 tons/haif sown on August 25. Winter cropssown at that time managed to form a shrub, cultivate the root system and provide higher productivityin the best possible termsbefore the vegetationperiodended. However, if sown early, it grows and develops well, but in the most cases it's less resistant to adverse conditions during winter hibernation. In the winter of 1955-1956, when sown late, the plants did not have enough time to form tillering nodes since autumn; so, the death rate in the spring constituted $40-50 \%$, while under the optimum terms of sowing the crops were completely killed [19, p. 64].

In the seventieth-the eightieth and subsequent years, the timing of winter wheat sowing started to be shifted due to the increase in agro technological process and the emergence of new intensive varieties (Table 1).

1. Yield of winter wheat, depending on the time of sowing, Kirovohrad sorting experimental plant, $t / h a$, the period of $1973-2000$.

\begin{tabular}{|c|c|c|c|c|c|c|c|c|c|}
\hline Years & \multicolumn{10}{|c|}{ Dateofsowing } \\
\cline { 2 - 10 } & 25.08 & 1.09 & 5.09 & 10.09 & 15.09 & 20.09 & 25.09 & 30.09 & 10.10 \\
\hline $\begin{array}{c}\text { Average } \\
1973-1980\end{array}$ & 5,86 & 4,72 & 6,08 & $\mathbf{6 , 3 4}$ & 6,12 & 5,78 & 5,55 & - & - \\
\hline $\begin{array}{c}\text { Average } \\
1981-1990\end{array}$ & 5,86 & 3,74 & 5,58 & $\mathbf{5 , 9 2}$ & $\mathbf{5 , 8 9}$ & 5,76 & 5,71 & - & - \\
\hline $\begin{array}{c}\text { Average } \\
1991-2000\end{array}$ & - & 5,02 & 5,50 & 5,95 & 5,28 & $\mathbf{6 , 5 1}$ & 6,15 & 5,97 & - \\
\hline
\end{tabular}

The data in the tables above indicate that the timing of winter wheat sowing does not remain constant. In the seventieth years the sowing time fell on September 10, while in the 90's -on September 20. Early sowing plants (from August 25 to September 5) develop rapidly and forma heavy shrub; before the onset of winter, they forma large vegetative mass, but cryoprotectants and mechanical tissue is not formed enough, that in turn determines the resistance of the plant organism to the cold, unfavorable conditions for hibernationand stress. Therefore, in 1982- 
1988, the rate of survival of plants in the winter when sown early (on August 25 ) reached $68.3 \%$, and when sown at optimum and later time (on September 20 and 25 ) - 95.6\% and $97.8 \%$ accordingly. This is especially noticeable in years with the long warm weather in the fall.

In the years of current century, as a result of climate irrigation and global warming, the steppe climate extends to theForest-steppe and the climatic zones are gradually shifted to the north. As a result, soil and air drought became more frequent in the autumn and spring-summer periods; in the period of optimal sowingthe lack of moisture is often observed; an extension of the terms of the plants'autumn vegetationis also observed. One can note soothing of the winter, frequent snow breaks, decrease in the duration of stable snow cover, changes in relative air humidity. The average temperature for the three winter months increased, while the duration of the cold period decreased.

All of the above affects the maintenance of plants with moisture, their growth and development, also worsens the confrontation with negative stress and makes it necessary to review the agro technological process of cultivating the culture and, first of all, the time of sowing (Table 2).

\section{Yield of soft winter wheat for different sowing times, Kirovohrad sorting experimental plant, t/ha}

\begin{tabular}{|l|l|l|c|c|c|c|c|c|}
\hline \multirow{2}{*}{ Years } & \multicolumn{1}{|l|}{ Dates } & \multicolumn{1}{|l|}{10.09} & 15.09 & 20.09 & 25.09 & 30.09 & 10.10 \\
\cline { 2 - 9 } & 1.09 & 5.09 & 10.09 & - & - \\
\hline $2001-2005$ & 2.45 & - & 6.19 & - & 6.35 & - & $\mathbf{6 . 6 1}$ & - \\
\hline $2006-2009$ & 6.98 & - & 7.38 & - & 7.72 & - & $\mathbf{7 . 9 6}$ & 7.53 \\
\hline $2011-2014$ & - & 5,32 & 5,94 & - & 6,33 & - & $\mathbf{7 , 0 9}$ & 6,92 \\
\hline
\end{tabular}

The data in the tables above show that in the first one and a half decades of this century, winter wheat forms the highest productivity if sown on September 30. Moreover, in the fifties, winter wheat sown earlier the optimal terms, yields higherproductivity than if sown later, and since the eighties, on the contrary, the later sown crops are more productive. That is, one of the directions of overcoming the negative impact of climate change and increasing the adaptability of plants may be to shift the sowing dates to later, with the definition of the optimal timing.

If sown early and moisturizedsufficiently, growth processes of plants pass faster, interphase periods are reduced, tillering begins earlier and is more active; until entering the winter period5-6 or more stems are formed. There are cases when plants in the fall prematurely skip to the next phases of development and stages of organogenesis, which under normal conditions should occur in the spring. The plantsovergrowth in the autumn in the conditions of the given zone is a negative factor. During early sowing (September 1-10), starting from the period of plant release in the tube and until the ear formation, the reduction of the weaker lateral stems and even the fallout of plantsare happening, which is affecting the level of productivity. Early crops are more damaged by pests and are affected by diseases. From the phytosanitary and economic point of view, they are unstable and require additional amount of fungicides and insecticidesto be applied to.

Later sown plants, but not very late (max. until October 10), that is, little younger, are more resistant to adverse conditions and they overwinter quite well. The author's research has established that for the years 1999-2001, the highest winter tolerance of such varieties as Donetska 48, ZnahidkaOdeska, Nikoniya and Yatran 60 was formed if sown on September 20 and 30,as well as on October 5. It's quite interesting that the plants sown on September 30 and October 5 entered the winter period at the beginning of their tillering, having only 1-2 sprouts. They hibernated quite well, grew and developed more intense and quickly in the spring, they also had a livelier dark green appearance, were almost completely preserved until harvest and formed higher yields. A similar situation was observed in 2016. Due to the longperiod without rains and the severe air-soil drought, the author took a decision on sowing in dry soil at scheduled time. Effective precipitation fell out only at the end of the first decade of October. The crops entered the winter period in the phase of a pip and with one or two leaves. The following spring was early, so moderate precipitation and temperature regime favored spring tilleringand the formations of a satisfactory productive plant stand. When sown onSeptember10, 20 and 30,the yield was formed almost the same, identical(4.26, 4.42, $4.48 \mathrm{t} / \mathrm{ha}$ accordingly) - at the level of statistical error; when sown on October $10-4.89 \mathrm{t} / \mathrm{ha}$, or higher, against the optimal term by $0.41 \mathrm{t} / \mathrm{ha}$.

Under thesecircumstances, the dilemma of choosing the right term of sowing is even more acute. In such situations, somewhat higher productivity is formed when sowing in dry soil at the end of the optimal and little bit laterterms. Precipitation, which in most years falls out in the middle of October, extended autumn vegetation period and moderate temperature conditions almost always contribute to the production of sprouts. They are often bushing out in the autumn, and in the long autumn they form 2-3 sprouts and overwintersatisfactorily or quite well.

Global climate change is also well traced in the area of researches. The average annual air temperature in the decade from 1951 to 1960 was $8,12^{\circ} \mathrm{C}$, in $1961-1970-8,06^{\circ} \mathrm{C}$, in $1971-1980-8,01^{\circ} \mathrm{C}$; then in $1981-1990$ it was $8,24^{\circ} \mathrm{C}$, in $1991-2000-8,67^{\circ} \mathrm{C}$, in $2001-2010-9,56^{\circ} \mathrm{C}$; and in the last seven years $(2011-2017)$ it was already $9,76^{\circ} \mathrm{C}$. Warming started from the beginning of the eighties, but it was slow then. Since the beginning of this century, it was quite intense. It largely adequately influenced the shifting of the optimal timing of winter wheat sowing, which since the 
beginning of the eighties tended to be changed towards later timing. Now sowing timing has shiftedto 30 days if compared to the 50's of the last century, to 20 daysif compared to the70's, to 15-20 daysif compared to the 80's and to 10 daysif compared to the 90's. It was established that during the period of thirty-three last years (1981-2014) the highest yield was obtained when sown in early terms (until September 5) - in 2 years; in admissible early terms (September10-15) -in 8 years, in optimum terms(September 20-30) in 20 years and in late terms (September 5-10) in 3 years. Thus, the probability of obtaining high productivity if sown early constitutes $6.0 \%$, if sown in admissible early timing- $24.0 \%$, if in optimal timing- $61 \%$, and in late terms- $9 \%$.

The researches revealed distinctive features of the adaptive reaction to the periods of sowing of different genotypes, which is most pronounced in the formation of productivity. In the fifties, such varieties as Odeska 3 , Odeska 16, Ukrainka 0246 produced higher yields when sown on August 25. In the seventieth-the nineties, the most of the varieties (Bezosta 1, Avrora, Kavkaz, Odeskasemidwarf, Donskasemidwarf, AlbatrosOdesky, Odeska 267, FantaziaOdeska and others) produced higher yieldswhen sown on September 10. Some varieties were more flexible and adaptive. In conditions of climate change, the reaction of new varieties in terms of sowing increases. During 20072009 and 2011-2014, modern varieties,such as Podolanka, Smuglyanka, Favoritka, Pereyaslavka, Zolotokolosa,produced the highest yields when sown on September 30; the varieties of Vinnytschanka, Selyankaand Kuyalnyk-on September 20; Bogdana-on September 30 and October 10.

Certainly, the results of old studies cannot be completely comparable with the present time ones, as the varieties of that time had other biological features, also other technical means and agro technologies were used. Therefore, the shifting of the optimal timing of sowing can be explained not only by the transformation of the climate, but also by the emergence of new genotypes with a lesser period of vernalization and photoperiodic sensitivity, with shortened phases of ontogenesis, which are more likely to be developed in the autumn, and which are more sensitive to early sowing, as well as by the latest agrotechnologies.

\section{Conclusions.}

Multi-yearexperimental data indicate a constant tendency to shift the timing of winter wheat sowing towardthe later ones: if compared to the 50's of the last century it's shifted to 30 days, if to the 70's -it's20 days, if to the 80's - 15-20 days, and if to the 90's - 10days. Under the condition of transformation of climate, sharp weather changes and extreme conditions, the introduction of modern varieties and nanoagrotechnologies, the optimal timing of winter wheat sowing in the conditions of the Southern part of the Right-Bank Forest-steppe of Ukraine falls on September 30 . The sowing timing is heavily dependent on the genotype.

In arid conditions, it is expedient to carry out sowing in a dry soil at the end of optimal and somewhat later terms.

\section{References}

1. Vorobjov S.A. (1929). Katastroficheskaja gibel' ozimyh posevov na Ukraine v $1927-1928$ gg. [Catastrophic death of winter crops in Ukraine in 1927 - 1928]. Har'kov. P. 9-13. [in Russian].

2. Fedorova N.A., Kostlan N.V. (1960). Morozo-stojkost' ozimyh kul'tur v zavisimosti ot vozrasta rastenij i uslovij vesennej vegetacii v rajonah Poles'ja i severnoj Lesostepi USSR. [Frost resistance of winter crops depending on the age of plants and conditions of spring vegetation in the regions of Polesye and northern forest-steppe of the USSR]. Fiziologija zimo-stojkosti rastenij. Moskva. P. 88-91. [in Russian].

3. Zhyvotkov L.O., Dushko M.V., Stepanko O.la. et al. (Zhyvotkov L.O. i Medvedovskyi O.K. Eds.) (1992). Resursozberihaiucha i ekolohichno chysta tekh-nolohiia vyroshchuvannia ozymoi pshenytsi. [Resource-saving and environmentally friendly technology of growing winter wheat]. Kyiv: Urozhai. 224 p. [in Ukrainian].

4. Demydov O., Kochmarskyi V., Kavunets V. ta in. (2016). Stroky sivby ozymoi pshenytsi: rekomendatsii ta realii. [Timing of winter wheat sowing: recommendations and realis] Пропозиція. № 10. P. 54-60. [in Ukrainian].

5. Lytvynenko M.A., Lyfenko S.P. (2004). Vplyv strokiv sivby i subletalnykh zymovykh temperatur na vyzhyvanist ta vrozhainist ozymoi pshenytsi. [Influence of sowing dates and sublethal winter temperatures on survival and yield of winter wheat]. Visn. ahrar. nauky. № 5. P. 27-31. [in Ukrainian].

6. Lykhochvor V. (2016). Sivba v optymalni stroky: yak ne prohadaty? [Seed in optimal terms: how not to lose sight?] Ahrobiznes sohodni. № 18 (337). P. 38-40. [in Ukrainian].

7. Tanchyk S.P., Mokriienko V.A., Motornyi V.A. (2014). Produktyvnist pshenytsi ozymoi zalezhno vid strokiv sivby. [Productivity of winter wheat depending on the time of sowing]. Nauk. dopov. Nats. un-tu bioresursiv $i$ pryrodokorystuvannia Ukrainy. № 2. P. 1-10. [in Ukrainian].

8. Khromiak V.M., Nalyvaiko V.V. (2016). Ryzyky vedennia roslynnytstva v umovakh Pivnichno-skhidnoho Stepu v zviazku zi zminoiu klimatu. [Risks of planting in the conditions of the Northeast Steppe due to climate change]. Visn. ahrar. nauky. № 9. P. 17-24. [in Ukrainian].

9. Korkhova M.M. (2015). Produktyvnist sortiv pshenytsi miakoi ozymoi zalezhno vid strokiv sivby ta norm vysivu v umovakh Pivdennoho Stepu Ukrainy: avtoref. ... dys. kand. s.-h. nauk. [Productivity of winter wheat varieties depending on sowing dates and seeding conditions in the conditions of the Southern Steppe of Ukraine] Kherson. 15 p. [in Ukrainian]. 
10. Netis I.T. (2011). Pshenytsia ozyma na Pivdni Ukrainy: monohr. [Winter wheat in the south of Ukraine: monograph.]. Kherson: Oldiplius. 460 p. [in Ukrainian].

11. Vozhehova R.A., Zaiets S.O., Kovalenko O.A. (2013).Urozhainist riznykh sortiv pshenytsi ozymoi zalezhno vid strokiv sivby $v$ umovakh Pivdennoho Stepu. [Yield of different varieties of winter wheat depending on the sowing dates in the Southern Steppe]. Visn. ahrar. nauky. P. $26-29$. [in Ukrainian].

12. Barbottin A., Lecomte C., Bouchard C., Jeuffroy M. - H. (2005). Nitrogen Remobilization during Grain Filling in Wheat. Genotypic and Environmental Effects. Crop. Sci, V. 45. P. $1141-1150$.

13. Skvorcova Yu.G., lonova E.V. (2015). Sroki poseva i posevnye kachestva semyan ozimoj myagkoj pshenicy. [Timing of sowing and seed quality of winter wheat]. Zernovoe hozyajstvo Rossii. 2015. C. $24-27$. [in Russian].

14. Kovyryalov Yu.P. (1985). Intensivnye tehnologicheskie sistemy vyrashivaniya zernovyh. [Intensive technological systems for growing cereals]. Zernovoe hozyajstvo Rossii. № 10. P. 35 - 37. [in Russian].

15. Ronis N.B. (1985). Intensivnaya tehnologiya vozdelyvaniya ozimoj pshenicy v Belgii. [Intensive technology of winter wheat cultivation in Belgium ]. Zernovoe hozyajstvo Rossii. № 11. P. 39 - 40. [in Russian].

16. Metodika gosudarstvennogo sortoispytaniya selskohozyajstvennyh kultur. [The method of state varietal testing of agricultural crops]. (1971). Moskva: Kolos,. Vyp. 2. 239 p. [in Russian].

17. Metodyka provedennia ekspertyzy ta derzhavnoho vyprobuvannia sortiv roslyn zernovykh, krupianykh ta zernobobovykh kultur. [Methodology of examination and state testing of varieties of plants of cereals, cereals and legumes]. (2003). Okhorona prav na sorty roslyn: ofits. biul. Kyiv. T. 2. Part. 3. P. 191 - 204. [in Ukrainian].

18. Metodyka provedennia ekspertyzy sortiv roslyn hrupy zernovykh, krupianykh ta zernobobovykh na prydatnist do poshyrennia v Ukraini (PSP). [The method of examination of varieties of plants of the group of grains, cereals and legumes for suitability for distribution in Ukraine (PSP)]. (2014). Kyiv: TOV «Niland-LTD». P. 4 - 12. [in Ukrainian].

19. Haliuk M.Kh., Shpuryk F.D. (1961). Osnovni ahrotekhnichni zakhody vyroshchuvannia ozymoi pshenytsi. [The main agrotechnical measures of growing of winter wheat]. Pidsumky nauk.-dosl. roboty po zernovykh i krupianykh kulturakh ta bahatorichnykh travakh: naukovi pratsi. Kyiv: Vyd. UASHN, 1961. Вип. 2. С. 67 -70. [in Ukrainian]. 